\title{
BILANGAN KROMATIK LOKASI PADA GRAF TOTAL DAN GRAF SPLITTING DARI GRAF BINTANG
}

\author{
Fransiskus Fran ${ }^{1}$, Novia Kristefany Kabang ${ }^{2}$, Yundari ${ }^{3}$ \\ 1,2,3 Jurusan Matematika FMIPA Universitas Tanjungpura, JI. Prof. Dr. H. Hadari Nawawi, Pontianak 78124, Indonesia \\ Email: fransiskusfran@math.untan.ac.id
}

\begin{abstract}
Let $G=(V, E)$ be a connected graph and $c$ be a coloring on graph $G$ so that $c(u) \neq c(v)$ is for $u$ id adjacent to $v$ in graphs $G, u, v \in G$. Let $C_{i}$ be a set of vertices that are colored $i$ for $i=1, \ldots, k$ which is called the color class. The color codes $\boldsymbol{c}_{\Pi}(u)$ of a vertex $u$ in $G$ is defined as the $k$-vector

$$
\boldsymbol{c}_{\Pi}(u)=\left(d\left(u, C_{1}\right), d\left(u, C_{2}\right), \cdots, d\left(u, C_{k}\right)\right) \text {, }
$$

where $d\left(u, C_{i}\right)=\min \left\{d(u, x) \mid x \in C_{i}\right\}$ untuk $1 \leq i \leq k, i, k \in \mathbb{N}$. If distinct vertices of $G$ have distinct color codes, then $c$ is called a locating coloring of $G$. the minimum number of colors used is called a locating chromatic number which is denoted by $\chi_{L}(G)$. Based on this research, we have $\chi_{L}\left(T\left(S_{n}\right)\right)=n+2, n=1,2$ and $\chi_{L}\left(T\left(S_{n}\right)\right)=n+1, n \geq 3, n \in \mathbb{N}$ where $T\left(S_{n}\right)$ is a total graph of $S_{n}$ and $\chi_{L}\left(S^{\prime}\left(S_{n}\right)\right)=n+2, n \in \mathbb{N}$, where $S^{\prime}\left(S_{n}\right)$ is a splitting graph of $S_{n}$.
\end{abstract}

Keywords: Color class, color code, locating coloring

\begin{abstract}
ABSTRAK
Misal diberikan graf terhubung $G=(V, E)$ dan $c$ menyatakan pewarnaan titik di $G$ sehingga untuk titik $u$ yang bertetangga dengan titik $v$ di $G, c(u) \neq c(v)$. Jika himpunan titik-titik yang mempunyai warna $i$ untuk $i=$ $1, \ldots, k$ dinyatakan dengan $C_{i}$, maka $C_{i}$ disebut kelas warna. Lebih lanjut, dapat ditentukan kode warna $\boldsymbol{c}_{\Pi}(u)$ untuk titik $u$ yaitu $k$-pasang terurut,

$$
\boldsymbol{c}_{\Pi}(u)=\left(d\left(u, C_{1}\right), d\left(u, C_{2}\right), \cdots, d\left(u, C_{k}\right)\right),
$$

dengan $d\left(u, C_{i}\right)=\min \left\{d(u, x) \mid x \in C_{i}\right\}$ untuk $1 \leq i \leq k, i, k \in \mathbb{N}$. Jika kode warna masing-masing titik di $G$ berbeda, maka pewarnaan $c$ adalah pewarnaan lokasi. Warna minimum (banyaknya warna) sehingga graf $G$ dapat diwarnai dengan pewarnaan lokasi dinyatakann dengan $\chi_{L}(G)$, disebut bilangan kromatik lokasi. Pada artikel ini, diperoleh bilangan kromatik lokasi untuk graf total dari graf bintang (dinotasikan $T\left(S_{n}\right)$ ) dan graf splitting dari graf bintang (dinotasikan $\left.S^{\prime}\left(S_{n}\right)\right)$ yaitu $\chi_{L}\left(T\left(S_{n}\right)\right)=n+2, n=1,2$ dan $\chi_{L}\left(T\left(S_{n}\right)\right)=n+1, n \geq 3$ dan $\chi_{L}\left(S^{\prime}\left(S_{n}\right)\right)=n+2, n \in \mathbb{N}$.
\end{abstract}

Kata kunci: Kelas warna, kode warna, pewarnaan lokasi

Dikirim: 29 April 2021; Diterima: 31 Agustus 2021; Dipublikasikan: 30 September 2021

Cara sitasi: Fran, F., Kabang, N. K., \& Yundari. (2021). Bilangan kromatik lokasi pada graf total dan graf splitting dari graf bintang. Teorema: Teori dan Riset Matematika, 6(2), 150-160. DOI: http://dx.doi.org/10.25157/teorema.v6i2.5322 


\section{PENDAHULUAN}

Matematika merupakan cabang ilmu yang sangat banyak berperan dalam membantu menyelesaikan berbagai persoalan. Salah satu ilmu yang dapat dikembangkan dalam matematika adalah teori tentang graf. Suatu graf $G$ merupakan pasangan himpunan $(V, E)$ dengan $V$ menyatakan himpunan titik-titik yang paling tidak memiliki satu titik (tidak kosong) dan $E$ menyatakan himpunan pasangan titik (sisi) pada graf $G$ (boleh berupa himpunan kosong) (Munir, 2010). Banyak sekali topik yang ada dalam teori graf misalnya topik yang terkait pewarnaan graf. Pada suatu graf, pewarnaan (proper coloring) merupakan suatu cara mewarnai (pemberian warna) elemen-elemen yang ada pada graf tersebut, dengan syarat bahwa dua elemen yang bertetangga diwarnai dengan warna berbeda.

Dalam pewarnaan graf, khususnya pewarnaan titik, terdapat beberapa pengembangan dengan menambahkan syarat tertentu, misalnya pewarnaan lokasi. Konsep pewarnaan lokasi suatu graf mengaitkan konsep pewarnaan titik dan dimensi partisi (Chartrand et al., 2002). Pewarnaan titik di $G$ merupakan pewarnaan lokasi jika kode warna titik-titik di $G$ berbeda. Pewarnaan lokasi pada suatu graf tidak hanya bertujuan mencari apakah suatu graf dikatakan memenuhi definisi pewarnaan lokasi saja, tetapi juga untuk mendapatkan warna minimum (banyaknya warna) pada pewarnaan lokasi tersebut yang selanjutnya dinamakan bilangan kromatik lokasi.

Walaupun sudah ada beberapa penelitian yang membahas terkait bilangan kromatik lokasi, namun karena banyaknya jenis graf dengan karakteristiknya masing-masing, sehingga penelitian lebih lanjut masih diperlukan. Pada artikel ini, difokuskan pada pembahasan mengenai bilangan kromatik lokasi pada graf hasil konstruksi dari graf lainnya, khususnya menggunakan konsep graf total dan graf splitting. Graf yang digunakan untuk memperoleh graf total dan graf splitting adalah graf bintang. Di sisi lain, dengan memperhatikan graf bintang yang bilangan kromatik lokasinya adalah $n+1$ (Kabang et al., 2020) dan adanya karakteristik yang dipertahankan oleh graf total dan graf splitting dari graf bintang, menjadi menarik untuk mengetahui relasi antara bilangan kromatik yang dihasilkan.

\section{METODE PENELITIAN}

Metode pada penelitian ini berupa kajian pustaka khususnya tentang konsep-konsep bilangan kromatik lokasi suatu graf (Chartrand et al., 2002), bilangan kromatik lokasi dari hasil kali Kartesian pada graf (Behtoei \& Omoomi, 2016), bilangan kromatik lokasi pada pohon (graf) tertentu yaitu graf $n T_{k, m}$ dan graf kembang api $\left(F_{n, k}\right)$ (Asmiati, 2016), bilangan kromatik lokasi dari graf barbel tertentu (Asmiati et al., 2018), serta bilangan kromatik lokasi dari graf bayangan dan graf middle (Kabang et al., 2020). Lebih lanjut, pada bagian pembahasan, ditentukan bilangan kromatik lokasi untuk graf total dari graf bintang $T\left(S_{n}\right)$ dan graf splitting dari graf bintang $S^{\prime}\left(S_{n}\right)$. Langkahlangkahnya yaitu menerapkan pewarnaan titik pada $T\left(S_{n}\right)$ dan $S^{\prime}\left(S_{n}\right)$. Kemudian, berdasarkan hasil kontruksi dari pewarnaan tersebut diperoleh kelas warna untuk semua titik, setelah itu dicari kode warna yang berisi jarak dari semua titik ke kelas warna di graf $T\left(S_{n}\right)$ dan $S^{\prime}\left(S_{n}\right)$. Jika kode warna untuk setiap titik pada graf $T\left(S_{n}\right)$ dan $S^{\prime}\left(S_{n}\right)$ berbeda, graf $T\left(S_{n}\right)$ dan $S^{\prime}\left(S_{n}\right)$ memenuhi definisi pewarnaan lokasi. Jika kode warna yang diperoleh sudah menggunakan warna minimum (banyaknya warna) maka diperoleh bilangan kromatik lokasi untuk graf $T\left(S_{n}\right)$ dan $S^{\prime}\left(S_{n}\right)$. Selain itu, digunakan pula beberapa sifat terkait bilangan kromatik lokasi (Chartrand et al., 2002), sehingga mempermudah dalam proses penentuan bilangan kromatik lokasi untuk graf $T\left(S_{n}\right)$ dan $S^{\prime}\left(S_{n}\right)$.

Untuk menentukan bilangan kromatik lokasi, diberikan beberapa konsep dasar berupa definisi dan teorema yang menjelaskan mengenai bilangan lokasi (dimensi metrik), dimensi partisi dan konsep terkait pewarnaan lokasi.

Definisi 1 (Xu et al., 2018) Misalkan $G=(V, E)$ adalah sebuah graf terhubung dan $W=$ $\left\{w_{1}, w_{2}, \ldots, w_{k}\right\}$ dimana $W$ merupakan subset dari $V(G)$. Untuk setiap titk $v \in V(G)$, kode lokasi dari $v$ ke $W$ adalah $k$-vektor $C_{W}(v)=\left(d\left(v, w_{1}\right), d\left(v, w_{2}\right), \cdots, d\left(v, w_{k}\right)\right)$ dan $W$ disebut 
himpunan lokasi dari $G$ jika titik-titik di $G$ mempunyai kode lokasi yang berbeda. Bilangan lokasi dari $G$ didefinisikan sebagai:

$$
\operatorname{Loc}(G)=\min \{|W|: W \text { adalah sebuah himpunan lokasi dari } G\} .
$$

Sebuah himpunan lokasi $W$ dari $G$ dikatakan himpunan lokasi minimum jika $|W|=\operatorname{Loc}(G)$.

Setelah mengetahui tentang himpunan lokasi dan bilangan lokasi, selanjutnya dibahas mengenai dimensi partisi pada Definisi 2.

Definisi 2 (Chartrand et al., 2000) Misal diberikan graf terhubung $G$, dengan $P$ merupakan subhimpunan dari $V(G)$ dan $u \in V(G)$, jarak titik $u$ ke $P$ dinyatakan dengan $d(u, P)$ yang didefiniskan sebagai $d(u, P)=\min \{d(u, x) \mid x \in P\}$. Untuk suatu pasangan terurut $k$-partisi, $\Pi=\left\{P_{1}, P_{2}, \cdots, P_{k}\right\}$ dari $V(G)$, representasi dari u terhadap $\Pi$ adalah $k$-pasang terurut

$$
r(u \mid \Pi)=\left(d\left(u, P_{1}\right), d\left(u, P_{2}\right), \cdots, d\left(u, P_{k}\right)\right),
$$

Jika untuk setiap $u \in V(G), k$-pasang terurut $r(u \mid \Pi)$ berbeda, maka partisi $\Pi$ merupakan partisi pembeda. Bilangan terkecil $k$ sehingga terdapat partisi pembeda untuk $V(G)$ disebut dimensi partisi di $G$ dan dilambangkan $p d(G)$.

Berdasarkan Definisi 2 dan konsep pewarnaan titik, dimensi partisi digunakan untuk mempartisi kelas warna di graf $G$ dan menentukan kode warna untuk semua titik pada graf $G$ sehingga diperoleh pewarnaan lokasi. Dimensi partisi dan pewarnaan lokasi sama-sama menggunakan konsep partisi. Bedanya, pada dimensi partisi titik-titik dipartisi tanpa menerapkan definisi pewarnaan pada graf, sehingga dua titik yang bertetangga boleh berada dalam satu partisi, sedangkan pada pewarnaan lokasi titik-titik dipartisi berdasarkan definisi pewarnaan titik sehingga titik-titik yang saling bertetangga tidak boleh berada dalam satu partisi kelas warna. Definisi konsepkonsep dalam pewarnaan lokasi disajikan pada Definisi 3, Definisi 4, dan Definisi 5.

Definisi 3 (Chartrand et al., 2002) Misalkan $G$ sebuah graf terhubung dan c merupakan pewarnaan titik pada $G$, sehingga $c(u) \neq c(v)$, untuk $u$ yang bertetangga dengan $v$ di $G$ dengan $u, v \in$ $V(G)$. Misalkan $C_{i}$ menyatakan himpunan semua titik yang diwarnai dengan warna $i$ dan disebut kelas warna, maka $\Pi=\left\{C_{1}, C_{2}, \cdots, C_{k}\right\}$ menyatakan himpunan semua kelas warna dari $V(G)$.

Banyaknya kelas warna yang ada pada suatu graf sama dengan banyaknya warna pada pewarnaan titik graf tersebut. Selanjutnya, berdasarkan kelas warna yang diperoleh, ditentukan kode warna masing-masing titik yang ada di $G$.

Definisi 4 (Chartrand et al., 2002) Kode warna $\boldsymbol{c}_{\Pi}(u)$ dari $V$ adalah k-pasang terurut

$$
\boldsymbol{c}_{\Pi}(u)=\left(d\left(u, C_{1}\right), d\left(u, C_{2}\right), \cdots, d\left(u, C_{k}\right)\right),
$$

dengan $d\left(u, C_{i}\right)=\min \left\{d(u, x) \mid x \in C_{i}\right\}$ untuk $1 \leq i \leq k, i, k \in \mathbb{N}$. Jika kode warna masingmasing titik di $G$ berbeda, pewarnaan $c$ disebut pewarnaan lokasi di $G$.

Berdasarkan Definisi 4, diketahui bahwa agar suatu pewarnaan titik merupakan pewarnaan lokasi, kode warna masing-masing titik di $G$ harus berbeda. Oleh karena kode warna untuk setiap titik merupakan jarak setiap titik ke semua kelas warna, maka banyaknya komponen kode warna untuk setiap titik sama dengan banyaknya warna untuk mewarnai titik-titik pada $G$.

Definisi 5 (Chartrand et al., 2002) Minimum warna (banyak warna) pada pewarnaan lokasi graf $G$ yang dinyatakan dengan $\chi_{L}(G)$ disebut bilangan kromatik lokasi graf $G$.

Seperti yang diketahui bahwa pewarnan lokasi juga merupakan pewarnaan titik pada suatu graf, akibatnya $\chi(G) \leq \chi_{L}(G)$. Agar lebih mudah dipahami, diberikan contoh mengenai Definisi 3, Definisi 4, dan Definisi 5 yang diilustrasikan pada Gambar 1. 


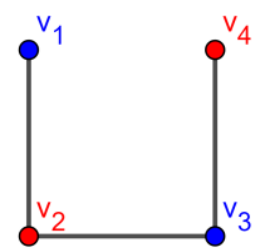

(a)

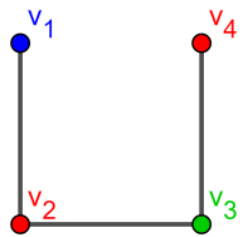

(b)

Gambar 1. (a) Graf $G$, (b) Graf $G_{2}$

Pada Gambar 1 bagian (a), sesuai definisi pewarnaan titik, minimal dapat digunakan 2 warna untuk mewarnai titik-titik di $G$, sehingga diperoleh $\chi(G)=2$. Oleh karena $\chi(G) \leq \chi_{L}(G)$, maka diperoleh $\chi_{L}(G) \geq 2$. Dari hasil konstruksi pewarnaan pada graf $G$, diperoleh kelas warna untuk semua titik: $C_{1}=\left\{v_{1}, v_{3}\right\}$ dan $C_{2}=\left\{v_{2}, v_{4}\right\}$. Setelah memperoleh kelas warna, selanjutnya menentukan kode warna masing-masing titik di graf $G$ sesuai dengan Definisi 4 , yang dinyatakan pada Tabel 1.

Tabel 1. Kode warna graf $G$

\begin{tabular}{llll}
\hline$V(G){ }^{C_{i}}$ & $C_{1}$ & $C_{2}$ & $\boldsymbol{c}_{\Pi}(V(G))$ \\
\hline$v_{1}$ & 0 & 1 & $(0,1)$ \\
$v_{2}$ & 1 & 0 & $(1,0)$ \\
$v_{3}$ & 0 & 1 & $(0,1)$ \\
$v_{4}$ & 1 & 0 & $(1,0)$ \\
\hline
\end{tabular}

Berdasarkan Tabel 1, titik $v_{1}, v_{3}$ dan $v_{2}, v_{4}$ pada graf $G$ memiliki kode warna yang sama. Oleh karena itu, pewarnaan pada graf $G$ yang menggunakan 2 warna tidak memenuhi Definisi 4. Oleh karena pewarnaan dengan 2 warna pada garf $G$ tidak memenuhi definisi pewarnaan lokasi, maka diterapkan pewarnaan ulang pada graf $G$. Graf $G$ yang sudah dilakukan pewarnaan ulang disimbolkan dengan graf $G_{2}$, dengan kelas warna yang diperoleh: $C_{1}=\left\{v_{1}\right\}, C_{2}=\left\{v_{2}, v_{4}\right\}$ dan $C_{3}=\left\{v_{3}\right\}$. Berdasarkan Definisi 4 , untuk setiap $v \in V\left(G_{2}\right)$, kode warna yang diperoleh diperlihatkan pada Tabel 2.

Tabel 2. Kode warna graf $G_{2}$

\begin{tabular}{|c|c|c|c|c|}
\hline$V\left(G_{2}\right) \quad C_{i}$ & $C_{1}$ & $C_{2}$ & $C_{3}$ & $\boldsymbol{c}_{\Pi}\left(V\left(G_{2}\right)\right)$ \\
\hline$v_{1}$ & 0 & 1 & 2 & $(0,1,2)$ \\
\hline$v_{2}$ & 1 & 0 & 1 & $(1,0,1)$ \\
\hline$v_{3}$ & 2 & 1 & 0 & $(2,0,1)$ \\
\hline$v_{4}$ & 3 & 0 & 1 & $(3,0,1)$ \\
\hline
\end{tabular}

Berdasarkan Tabel 2, kode warna masing-masing titik di graf $G_{2}$ berbeda. Akibatnya, pewarnaan graf $G_{2}$ dengan menggunakan 3 warna merupakan pewarnaan lokasi dan merupakan jumlah warna minimum, sehingga diperoleh $\chi_{L}\left(G_{2}\right)=3$.

Definisi 6 (Yuliantina \& Budayasa, 2018) Misal $G=(V(G), E(G))$ sebuah graf dan $v$ sebuah titik di $G$. Persekitaran terbuka titik $v$, dilambangkan dengan $N_{G}(v)$ atau $N(v)$, didefinisikan sebagai $N(v)=\{x \in V(G) \mid v x \in E(G)\}$ yang merupakan himpunan titik-titik yang bertetangga dengan titik $v$ di $G$. Sedangkan persekitaran tertutup untuk titik $v$, dilambangkan $N[v]$ dan didefinisikan sebagai $N[v]=N(v) \cup\{v\}$.

Setelah membahas tentang persekitaran titik $v \in V(G)$, selanjutnya dibahas mengenai warna-warna untuk semua titik yang ada di sekitar titik $v$ seperti pada Teorema 7 beserta akibatnya.

Teorema 7 (Chartrand et al., 2002) Misalkan $G$ graf terhubung dan c merupakan pewarnaan lokasi di $G$. Jika $u, v \in V(G), u \neq v$ sedemikian sehingga $d(u, w)=d(v, w)$ untuk setiap $w \in$ 
$V(G)-\{u, v\}$, maka $c(u) \neq c(v)$. Secara khusus, jika $u$ tidak bertetangga dengan $v$ di $G$ dan $N(u)=N(v)$, maka $c(u) \neq c(v)$.

Berdasarkan Teorema 7, dapat diartikan bahwa kedua titik yaitu titik $u$ dan $v$ pasti berada didalam kelas warna yang berbeda, dikarenakan titik $u$ dan $v$ memiliki persekitaran yang sama. Pada kondisi tersebut, jika titik $u$ dan $v$ memiliki warna sama, maka Definisi 4 tidak dapat dipenuhi. Lebih lanjut, Teorema 7 ini menghasilkan akibat sebagai berikut.

Akibat 8 (Chartrand et al., 2002) Diberikan graf terhubung G. Jika terdapat suatu titik yang bertetangga dengan $n$ daun di $G$, maka $\chi_{L}(G) \geq n+1$.

Akibat 8 ini, memberikan batas bawah bilangan kromatik lokasi suatu graf yang memiliki titik dan bertetangga dengan $n$ daun. Sebagai contoh, diberikan ilustrasi pada Gambar 2.

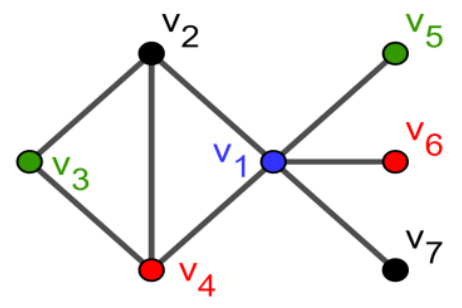

Gambar 2. Graf $X$

Pada Gambar 2, dapat dilihat bahwa, graf $X$ yang memiliki 7 titik dengan titik $v_{1}$ bertetangga dengan 3 daun. Menurut Akibat $8, \chi_{L}(X) \geq 4$.

\section{HASIL DAN PEMBAHASAN}

Pada artikel ini, secara khusus dibahas mengenai bilangan kromatik lokasi dari graf yang diperoleh menggunakan konsep graf total dan graf splitting. Lebih khusus, graf dasar yang digunakan adalah graf bintang yang yang selanjutnya dikonstruksi menjadi graf total dan graf splitting. Untuk itu, terlebih dahulu diberikan definisi graf bintang.

Definisi 9 (Irawati \& Dina, 2013) Graf bintang yang dinotasikan dengan $S_{n}$ merupakan graf yang memiliki $n+1$ titik, dengan 1 titik pusat berderajat $n, n \in \mathbb{N}$ yang bertetangga dengan $n$ daun.

Agar lebih mudah dipahami, diberikan ilustrasi gambar seperti Gambar 3 untuk menjelaskan Definisi 9. Berdasarkan Gambar 3, dapat dilihat bahwa titik $u$ sebagai titik pusat dan titik $v_{1}, v_{2}, \ldots, v_{n}$ sebagai daun. Jika dikaitkan dengan pewarnaan lokasi dan memperhatikan Akibat 8 , diperoleh $\chi_{L}\left(S_{n}\right) \geq n+1$.

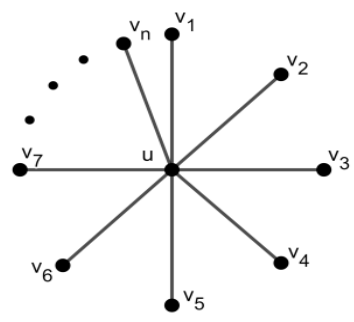

\section{Gambar 3. Graf Bintang $\left(S_{n}\right)$}

Dari graf bintang tersebut, diterapkan konsep graf total dan graf splitting berturut-turut menggunakan Definisi 10 dan Definisi 11.

Definisi 10 (Thenmozhi \& Prabha, 2017) Misal diberikan graf $G=(V(G), E(G))$. Graf total dari graf $G$ yang dinotasikan $T(G)$ adalah graf yang himpunan titiknya adalah $V(G) \cup U(G)$, dengan $U(G)$ menyatakan himpunan titik-titik baru berdasarkan penambahan satu titik untuk masing-masing sisi $e=v_{i} v_{j}$ pada graf $G$. Dalam graf total, dua titik bertetangga di $T(G)$ jika dan hanya jika, 
(i) $v_{i} \in V(G)$ bertetangga dengan $v_{j} \in V(G)$ di $G$ untuk $i \neq j$ dimana $i, j=$ $1, \ldots,|V(G)|$.

(ii) $u_{i} \in U(G)$ bertetangga dengan $u_{j} \in U(G)$, jika sisi $e_{i}$ dan $e_{j}$ bersisian dengan titik yang sama di graf $G$ untuk $i \neq j$ dimana $i, j=1, \ldots,|V(G)|$

(iii) $v_{i}$ bertetangga dengan $u_{i} \in V(T(G))$ jika $v_{i}$ bersisian dengan sisi $e_{j}$ dengan $i \neq j$ dimana $i, j=1, \ldots,|V(G)|$.

Definisi 11 (Ghosh et al., 2015) Graf splitting dari graf terhubung $G$ dinotasikan dengan $S^{\prime}(G)$ merupakan graf yang diperoleh dari graf $G$ dengan penambahan titik baru $u^{\prime}$ untuk masing-masing titik $u$ di $G$ sehingga $N(u)=N\left(u^{\prime}\right)$, dengan $N(u)$ dan $N\left(u^{\prime}\right)$ berturut-turut merupakan persekitaran terbuka titik $u$ dan $u^{\prime}$.

Menerapkan Definisi 10 dan Definisi 11, ilustrasi graf total dan graf splitting dari graf bintang dinyatakan pada Gambar 4.

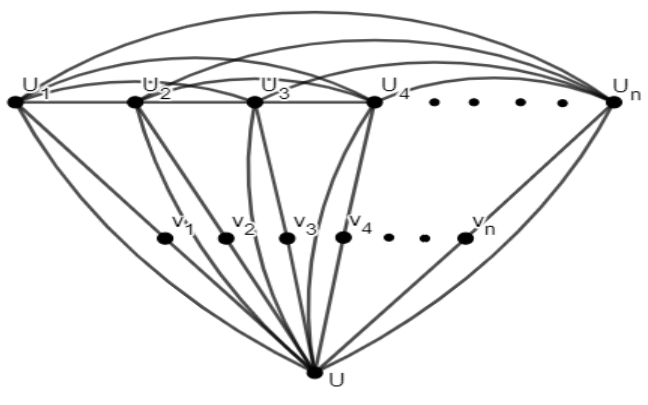

(a)

Gambar 4. (a) Graf $T\left(S_{n}\right)$, (b) Graf $S^{\prime}\left(S_{n}\right)$

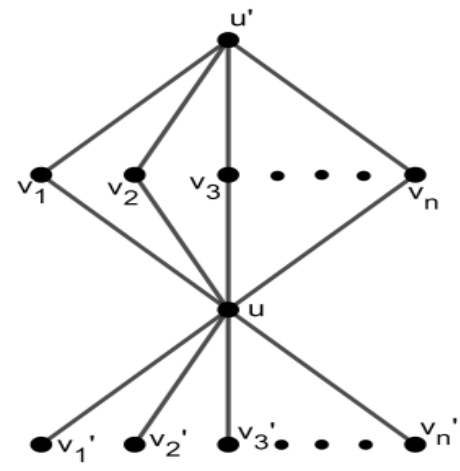

(b)

Setelah diberikan definisi pewarnaan lokasi dan konsep terkait serta cara pembentukkan graf baru berdasarkan Definisi 10 dan Definisi 11, selanjutnya konsep pewarnaan lokasi diterapkan pada graf total dari graf bintang $T\left(S_{n}\right)$ yang memiliki $2 n+1$ titik dan graf splitting dari graf bintang $S^{\prime}\left(S_{n}\right)$ yang memiliki $2 n+1$ sehingga bilangan kromatik dari kedua graf tersebut.

Pada proses ini, dilakukan konstruksi pewarnaan lokasi sehingga diperoleh kelas warna dan kode lokasi yang berbeda untuk masing-masing titik pada graf $T\left(S_{n}\right)$ dan $S^{\prime}\left(S_{n}\right)$. Untuk keperluan tersebut, konsep pewarnaan titik dan relasi antara bilangan kromatik dan bilangan kromatik lokasi, serta sifat yang telah diberikan pada Teorema 7 dan Akibat 8 juga merupakan bagian yang saling mendukung. Hal tersebut dapat digunakan untuk memverifikasi hasil bilangan kromatik lokasi yang diperoleh. Bilangan kromatik lokasi untuk graf $T\left(S_{n}\right)$ dan $S^{\prime}\left(S_{n}\right)$ berturut-turut dinyatakan pada Teorema 12 dan Teorema 13.

Teorema 12 Diberikan graf bintang $S_{n}$ dengan $T\left(S_{n}\right)$ merupakan graf total dari $S_{n}, n \in \mathbb{N}$. Bilangan kromatik lokasi untuk $T\left(S_{n}\right)$ adalah

\section{Bukti :}

$$
\chi_{L}\left(T\left(S_{n}\right)\right)= \begin{cases}3, & n=1 \\ 4, & n=2 \\ n+1, & n \geq 3\end{cases}
$$

(i) $\chi_{L}\left(T\left(S_{n}\right)\right)=3$, untuk $n=1$

Pertama, dengan menerapkan pewarnaan titik pada $T\left(S_{1}\right)$, diperoleh $\chi\left(T\left(S_{1}\right)\right)=3$. Lebih lanjut, karena $\chi(G) \leq \chi_{L}(G)$, maka $\chi_{L}\left(T\left(S_{1}\right)\right) \geq 3$. Kemudian dikonstruksi pewarnaan, sehingga kelas warna yang diperoleh adalah:

$$
\begin{aligned}
& C_{1}=\left\{u_{1}\right\} \\
& C_{2}=\left\{v_{1}\right\} \\
& C_{3}=\{u\}
\end{aligned}
$$


Berdasarkan kelas warna (1), (2) dan (3), kode warna yang diperoleh adalah:

$$
\begin{aligned}
& \boldsymbol{c}_{\Pi}\left(u_{1}\right)=(0,1,1) \\
& \boldsymbol{c}_{\Pi}\left(v_{1}\right)=(1,0,1) \\
& \boldsymbol{c}_{\Pi}(u)=(1,1,0)
\end{aligned}
$$

Berdasarkan kode warna tersebut, kode warna yang diperoleh untuk titik-titik pada $T\left(S_{1}\right)$ berbeda. Dari kode warna tersebut, diperoleh $\chi_{L}\left(T\left(S_{1}\right)\right) \leq 3$. Oleh karena itu, $3 \leq$ $\chi_{L}\left(T\left(S_{1}\right)\right) \leq 3$. Akibatnya, dapat disimpulkan bahwa $\chi_{L}\left(T\left(S_{1}\right)\right)=3$. Untuk memperjelas hasil formula yang diperoleh, diberikan contoh aplikasi dari formula tersebut seperti pada Gambar 5.

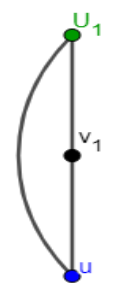

\section{Gambar 5. Graf $T\left(S_{1}\right)$}

(ii) $\chi_{L}\left(T\left(S_{n}\right)\right)=4$, untuk $n=2$

Pada graf $T\left(S_{2}\right)$, diterapkan suatu pewarnaan titik sehingga kelas warna yang diperoleh adalah: $C_{1}=\left\{u_{1}\right\}, C_{2}=\left\{u_{2}\right\}, C_{3}=\left\{v_{1}, v_{2}\right\}$, dan $C_{4}=\{u\}$. Untuk setiap titik di graf $T\left(S_{2}\right)$, diperoleh kode warna:

$$
\begin{aligned}
\boldsymbol{c}_{\Pi}(u) & =\left(d\left(u, C_{1}\right), d\left(u, C_{2}\right), d\left(u, C_{3}\right), d\left(u, C_{4}\right)\right) \\
& =(1,1,1,0) \\
\boldsymbol{c}_{\Pi}\left(v_{1}\right) & =\left(d\left(v_{1}, C_{1}\right), d\left(v_{1}, C_{2}\right), d\left(v_{1}, C_{3}\right), d\left(v_{1}, C_{4}\right)\right) \\
& =(1,2,0,1) \\
\boldsymbol{c}_{\Pi}\left(v_{2}\right) & =\left(d\left(v_{2}, C_{1}\right), d\left(v_{2}, C_{2}\right), d\left(v_{2}, C_{3}\right), d\left(v_{2}, C_{4}\right)\right) \\
& =(2,1,0,1) \\
\boldsymbol{c}_{\Pi}\left(u_{1}\right) & =\left(d\left(u_{1}, C_{1}\right), d\left(u_{1}, C_{2}\right), d\left(u_{1}, C_{3}\right), d\left(u_{1}, C_{4}\right)\right) \\
& =(0,1,1,1) \\
\boldsymbol{c}_{\Pi}\left(u_{2}\right) & =\left(d\left(u_{2}, C_{1}\right), d\left(u_{2}, C_{2}\right), d\left(u_{2}, C_{3}\right), d\left(u_{2}, C_{4}\right)\right) \\
& =(1,0,1,1)
\end{aligned}
$$

Berdasarkan kode-kode warna tersebut, kode warna yang diperoleh untuk masing-masing titik pada $T\left(S_{2}\right)$ berbeda, berakibat $\chi_{L}\left(T\left(S_{2}\right)\right) \leq 4$. Oleh karena $\chi(G) \leq \chi_{L}(G)$, selanjutnya dilakukan pewarnaan titik pada $T\left(S_{2}\right)$ dan diperoleh $\chi\left(T\left(S_{2}\right)\right)=3$. Akibatnya, $3 \leq$ $\chi_{L}\left(T\left(S_{2}\right)\right) \leq 4$. Berdasarkan hasil yang ada, diperoleh kemungkinan $\chi_{L}\left(T\left(S_{2}\right)\right)=3$ atau $\chi_{L}\left(T\left(S_{2}\right)\right)=4$. Andaikan $\chi_{L}\left(M\left(S_{2}\right)\right)=3$, artinya minimal digunakan 3 warna untuk pewarnaan lokasi $T\left(S_{2}\right)$. Oleh karena titik $u, u_{1}$ dan $u_{2}$ saling bertetangga, maka diperlukan 3 warna untuk mewarnai masing-masing titik $u, u_{1}$ dan $u_{2}$. Selanjutnya, untuk titik $v_{1}$ dan $v_{2}$ yang belum memiliki warna, karena sudah 3 warna yang digunakan, maka harus diwarnai dengan warna yang sudah ada. Pada graf $T\left(S_{2}\right)$, titik $v_{1}$ betetangga dengan titik $u$ dan $u_{1}$, sehingga warna untuk titik $v_{1}$ harus berbeda dengan warna $u$ dan $u_{1}$. Akibatnya, $v_{1}$ harus mempunyai warna yang sama dengan $u_{2}$. Hal yang sama berlaku untuk $v_{2}$. Berdasarkan pewarnaan tersebut, kelas warna untuk graf $T\left(S_{2}\right)$ adalah $C_{1}=\{u\}, C_{2}=\left\{u_{1}, v_{2}\right\}$, dan $C_{3}=\left\{u_{2}, v_{1}\right\}$. Kode warna untuk titik-titik di $T\left(S_{2}\right)$ berdasarkan kelas warna adalah:

$$
\begin{aligned}
c_{\Pi}(u) & =\left(d\left(u, C_{1}\right), d\left(u, C_{2}\right), d\left(u, C_{3}\right)\right) \\
& =(0,1,1) \\
c_{\Pi}\left(v_{1}\right) & =\left(d\left(v_{1}, C_{1}\right), d\left(v_{1}, C_{2}\right), d\left(v_{1}, C_{3}\right)\right) \\
& =(1,1,0)
\end{aligned}
$$




$$
\begin{aligned}
\boldsymbol{c}_{\Pi}\left(v_{2}\right) & =\left(d\left(v_{2}, C_{1}\right), d\left(v_{2}, C_{2}\right), d\left(v_{2}, C_{3}\right)\right) \\
& =(1,0,1) \\
\boldsymbol{c}_{\Pi}\left(u_{1}\right) & =\left(d\left(u_{1}, C_{1}\right), d\left(u_{1}, C_{2}\right), d\left(u_{1}, C_{3}\right)\right) \\
& =(1,0,1) \\
\boldsymbol{c}_{\Pi}\left(u_{2}\right) & =\left(d\left(u_{2}, C_{1}\right), d\left(u_{2}, C_{2}\right), d\left(u_{2}, C_{3}\right)\right) \\
& =(1,1,0)
\end{aligned}
$$

Diperoleh bahwa kode warna $u_{1}$ dan $v_{2}$ serta kode warna $u_{2}$ dan $v_{1}$ adalah sama. Akibatnya, pewarnaan titik menggunakan 3 warna untuk graf $T\left(S_{2}\right)$ tidak memenuhi definisi pewarnaan lokasi (kontradiksi). Agar pewarnaan titik pada graf $T\left(S_{2}\right)$ memenuhi definisi pewarnaan lokasi, haruslah $\chi_{L}\left(T\left(S_{2}\right)\right) \geq 4$. Oleh karena itu, diperoleh bahwa $\chi_{L}\left(T\left(S_{2}\right)\right)=4$. Untuk memperjelas hasil formula yang diperoleh, diberikan contoh aplikasi dari formula tersebut seperti pada Gambar 6.

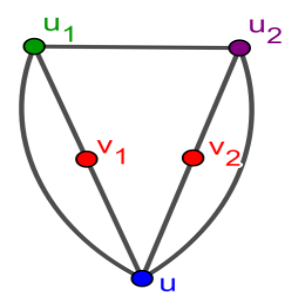

Gambar 6. Graf $T\left(S_{2}\right)$

(iii) $\chi_{L}\left(T\left(S_{n}\right)\right)=n+1$, untuk $n \geq 3$

Terlebih dahulu, dikonstruksi pewarnaan titik untuk $T\left(S_{n}\right)$. Titik-titik $u_{i}$ di $T\left(S_{n}\right)$ dengan $i=$ $1, \ldots, n$ saling bertetangga, sehingga dibutuhkan $n$ warna untuk mewarnai masing-masing titik $u_{i}$. Untuk titik-titik $v_{i}$, dapat diwarnai menggunakan $n$ warna yang sudah digunakan untuk mewarnai titik-titik $u_{i}$, sesuai definisi pewarnaan titik. Pada graf $T\left(S_{n}\right)$, tersisa titik $u$ yang belum diwarnai. Oleh karena titik $u$ bertetangga dengan masing-masing titik $u_{i}$, sehingga berdasarkan definisi pewarnaan titik, warna untuk titik $u$ harus berbeda dengan warna masingmasing titik $u_{i}$. Oleh kerena itu, diperoleh $\chi\left(T\left(S_{n}\right)\right)=n+1$. Akibatnya, $\chi_{L}\left(T\left(S_{n}\right)\right) \geq$ $n+1$.

Selanjutnya akan ditunjukkan bahwa $\chi_{L}\left(T\left(S_{n}\right)\right) \leq n+1$. Berdasarkan hasil konstruksi pewarnaan titik untuk $T\left(S_{n}\right)$, kelas warna yang diperoleh adalah:

$$
\begin{aligned}
& C_{i}=\left\{u_{i}, v_{i+1}\right\}, \text { untuk } i=1, \ldots, n-1 \\
& C_{n}=\left\{u_{n}, v_{1}\right\} \\
& C_{n+1}=\{u\}
\end{aligned}
$$

Berdasarkan kelas warna (4), (5) dan (6), kode warna yang diperoleh adalah:

$$
\begin{aligned}
& \boldsymbol{c}_{\Pi}(u)=\left\{\begin{array}{l}
0, \text { komponen ke } n+1 \\
1, \text { komponen lainnya }
\end{array}\right. \\
& \boldsymbol{c}_{\Pi}\left(v_{1}\right)=\left\{\begin{array}{l}
1, \text { komponen ke } 1 \text { dan } n+1 \\
0, \text { komponen ke } n \\
2, \text { komponen lainnya }
\end{array}\right. \\
& \boldsymbol{c}_{\Pi}\left(u_{i}\right)=\left\{\begin{array}{l}
0, \text { komponen ke } i \\
1, \text { komponen lainnya }
\end{array}\right. \\
& \boldsymbol{c}_{\Pi}\left(v_{i}\right)=\left\{\begin{array}{l}
0, \text { komponen ke } i-1 \\
1, \text { komponen ke } i \text { dan } n+1 \\
2, \text { komponen lainnya }
\end{array}\right. \\
& \boldsymbol{c}_{\Pi}\left(v_{2}\right)=\left\{\begin{array}{l}
0, \text { komponen ke } 1 \\
1, \text { komponen ke } 2 \text { dan } n+1 \\
2, \text { komponen lainnya }
\end{array}\right.
\end{aligned}
$$


Akibatnya, menurut Definisi 4 dan Definisi 5 menunjukkan $\chi_{L}\left(T\left(S_{n}\right)\right) \leq n+1$. Oleh karena diperoleh $n+1 \leq \chi_{L}\left(T\left(S_{n}\right)\right) \leq n+1$, maka $\chi_{L}\left(T\left(S_{n}\right)\right)=n+1$.

Untuk memperjelas hasil formula yang diperoleh, diberikan contoh aplikasi dari formula tersebut seperti pada Gambar 7.

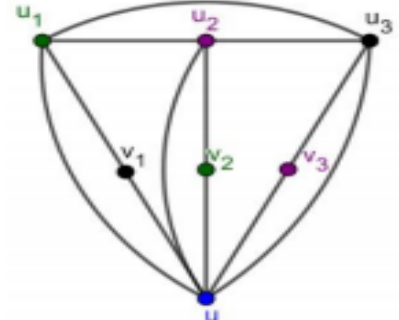

(a)

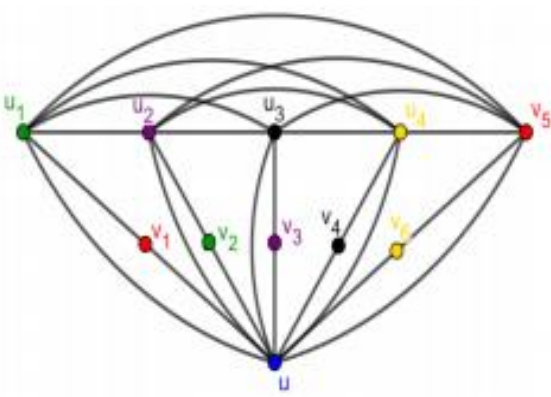

(c)

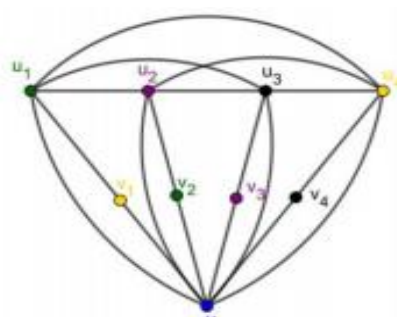

(b)

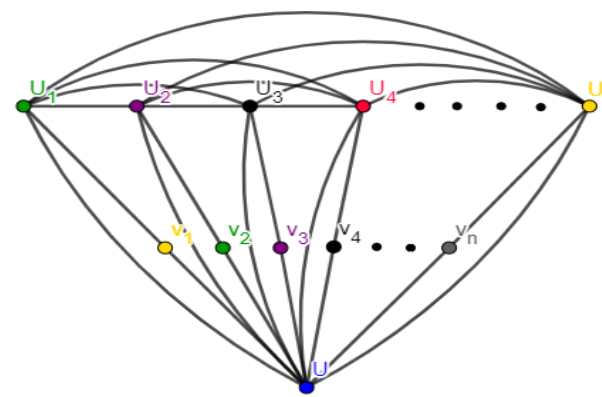

(d)

Gambar 7. (a) Graf $T\left(S_{3}\right)$, (b) Graf $T\left(S_{4}\right)$, (c) Graf $T\left(S_{5}\right)$, (d) Graf $T\left(S_{n}\right)$

Pada Teorema 12, telah diberikan bilangan kromatik lokasi untuk graf total dari graf bintang $T\left(S_{n}\right)$. Selanjutnya, konsep pewarnaan lokasi juga diterapkan pada graf splitting dari graf bintang $S^{\prime}\left(S_{n}\right)$ sehingga diperoleh bilangan kromatik lokasi dari $S^{\prime}\left(S_{n}\right)$ yang dinyatakan pada Teorema 13.

Teorema 13 Diberikan graf bintang $S_{n}$ dengan $S^{\prime}\left(S_{n}\right)$ merupakan graf splitting dari $S_{n}, n \in \mathbb{N}$. Bilangan kromatik lokasi untuk $T\left(S_{n}\right)$ adalah $\chi_{L}\left(S^{\prime}\left(S_{n}\right)\right)=n+2$.

\section{Bukti :}

Persekitaran terbuka titik-titik $v_{i}$ dengan $i=1, \ldots, n$ di $S^{\prime}\left(S_{n}\right)$ adalah sama atau $N\left(v_{1}\right)=$ $N\left(v_{2}\right)=N\left(v_{3}\right)=\cdots=N\left(v_{n}\right)$. Berdasarkan Teorema 7, maka untuk masing-masing titik $v_{i}$ harus diwarnai dengan warna berbeda. Akibatnya, diperlukan $n$ warna sehingga masing-masing titik $v_{i}$ memiliki warna yang berbeda. Selanjutnya, tinjau kedua titik yang saling bertetangga dengan titik $v_{i}$ yaitu titik $u_{1}$ dan $u_{1}{ }^{\prime}$. Sehingga, titik $u_{1}$ dan $u_{1}{ }^{\prime}$ tidak dapat diwarnai dengan warna yang telah digunakan untuk mewarnai titik-titik $v_{i}$. Lebih lanjut, diperoleh juga bahwa persekitaran terbuka titik $u_{1}$ dan $u_{1}{ }^{\prime}$ adalah sama atau $N\left(u_{1}\right)=N\left(u_{1}{ }^{\prime}\right)$. Menurut Teorema 7 , hal tersebut berakibat bahwa titik $u_{1}$ dan titik $u_{1}{ }^{\prime}$ harus diwarnai dengan warna berbeda (diperlukan 2 warna tambahan dari warna yang sudah ada). Diperoleh bahwa, dibutuhkan $n+2$ warna untuk mewarnai semua $v_{i}, u_{1}$ dan $u_{1}{ }^{\prime}$. Tanpa memperhatikan titik-titik $v_{i}{ }^{\prime}$ dengan $i=1, \ldots, n$, diperoleh bahwa setidaknya, diperlukan $n+2$ warna untuk mewarnai titik-titik yang ada pada graf $S^{\prime}\left(S_{n}\right)$ atau $\chi_{L}\left(S^{\prime}\left(S_{n}\right)\right) \geq$ $n+2$.

Selanjutnya, dibentuk konstruksi kelas warna berdasarkan pewarnaan yang telah diterapkan di graf $S^{\prime}\left(S_{n}\right)$, sehingga kelas warna yang diperoleh adalah:

$$
\begin{aligned}
C_{i} & =\left\{v_{i}, v_{i}{ }^{\prime}\right\}, \text { untuk } i=1, \ldots, n \\
C_{n+1} & =\left\{u_{1}\right\} \\
C_{n+2} & =\left\{u_{1}{ }^{\prime}\right\}
\end{aligned}
$$


Berdasarkan kelas warna (7), (8) dan (9), kode warna yang diperoleh adalah:

$$
\begin{aligned}
& \boldsymbol{c}_{\Pi}\left(v_{i}\right)=\left\{\begin{array}{l}
0, \quad \text { komponen ke } i \\
1, \text { komponen ke } n+1 \\
1, \text { komponen ke } n+2 \\
2, \text { komponen lainnya }
\end{array}\right. \\
& \boldsymbol{c}_{\Pi}\left(v_{i}^{\prime}\right)=\left\{\begin{array}{l}
0, \text { komponen ke } i \\
1, \text { komponen ke } n+1 \\
3, \text { komponen ke } n+2 \\
2, \text { komponen lainnya }
\end{array}\right. \\
& \boldsymbol{c}_{\Pi}\left(u_{1}\right)=\left\{\begin{array}{l}
0, \text { komponen ke } n+1 \\
2, \text { komponen ke } n+2 \\
1, \text { komponen lainnya }
\end{array}\right. \\
& \boldsymbol{c}_{\Pi}\left(u_{1}{ }^{\prime}\right)=\left\{\begin{array}{l}
0, \text { komponen ke } n+2 \\
2, \text { komponen ke } n+1 \\
1, \text { komponen lainnya }
\end{array}\right.
\end{aligned}
$$

Berdasarkan kode warna tersebut, dapat dilihat bahwa masing-masing titik $v_{i}{ }^{\prime}$ dan $v_{i}$ dapat diwarnai dengan warna yang sama. Walaupun titik $v_{i}{ }^{\prime}$ dan $v_{i}$ terdapat pada kelas warna yang sama tetapi kode warna untuk titik $v_{i}{ }^{\prime}$ dan $v_{i}$ berbeda. Akibatnya, berdasarkan kode warna tersebut serta Definisi dan Definisi 5, $\chi_{L}\left(S^{\prime}\left(S_{n}\right)\right) \leq n+2$. Oleh karena, $n+2 \leq \chi_{L}\left(S^{\prime}\left(S_{n}\right)\right) \leq n+2$, diperoleh $\chi_{L}\left(S^{\prime}\left(S_{n}\right)\right)=n+2$.

Untuk memperjelas hasil formula yang diperoleh, diberikan contoh aplikasi dari formula tersebut seperti pada gambar 8 .

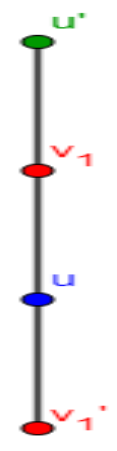

(a)

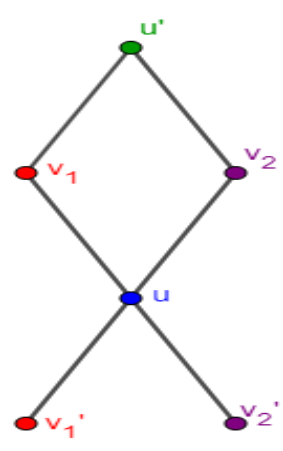

(b)

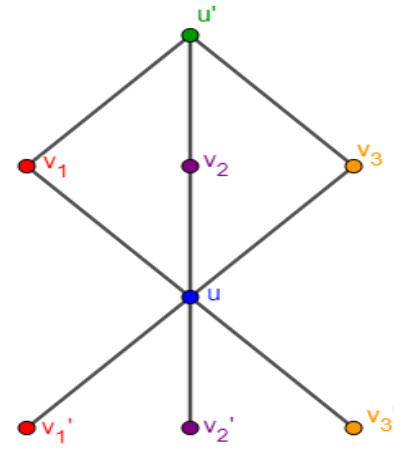

(c)

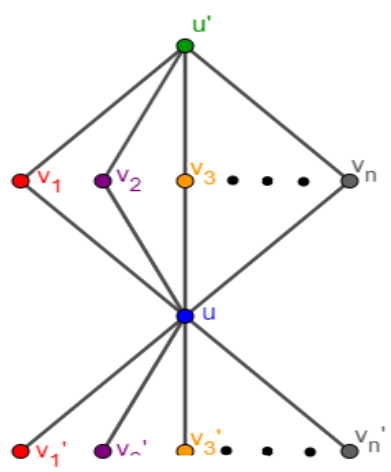

(d)

Gambar 8. (a) Graf $S^{\prime}\left(S_{1}\right)$, (b) Graf $S^{\prime}\left(S_{2}\right)$, (c) Graf $S^{\prime}\left(S_{3}\right)$, (d) Graf $S^{\prime}\left(S_{4}\right)$

\section{KESIMPULAN}

Bilangan kromatik lokasi suatu graf $G$ yang dilambangkan dengan $\chi_{L}(G)$ menyatakan minimal banyaknya warna yang digunakan pada pewarnaan lokasi, sehingga kode warna masingmasing titik di $G$ berbeda. Pada artikel ini, diperoleh bilangan kromatik lokasi pada graf hasill konstruksi yaitu graf total dan graf splitting dari graf bintang. Bilangan kromatik lokasi pada graf total dari graf bintang $T\left(S_{n}\right)$ dan graf splitting dari graf bintang $S^{\prime}\left(S_{n}\right)$ berturut-turut adalah $\chi_{L}\left(T\left(S_{n}\right)\right)=n+2, n=1,2$ dan $\chi_{L}\left(T\left(S_{n}\right)\right)=n+1, n \geq 3$ dan $\chi_{L}\left(S^{\prime}\left(S_{n}\right)\right)=n+2$ untuk $n \in \mathbb{N}$. Oleh karena $\chi_{L}\left(S_{n}\right)=n+1$, yang berarti $\chi_{L}\left(T\left(S_{n}\right)\right)=\chi_{L}\left(S_{n}\right), n \geq 3$ dan $\chi_{L}\left(S^{\prime}\left(S_{n}\right)\right)=\chi_{L}\left(S_{n}\right)+1$.

\section{REKOMENDASI}

Berdasarkan hasil penelitain, telah diperoleh bilangan kromatik lokasi pada graf total dari graf bintang $T\left(S_{n}\right)$ dan graf splitting dari graf bintang $S^{\prime}\left(S_{n}\right)$. Untuk graf-graf lainnya, khususnya yang diperoleh dari hasil operasi maupun konstruksi suatu graf, tentunya dapat memiliki bilangan 
kromatik yang berbeda-beda sesuai karakteristiknya masing-masing. Untuk itu, dapat dilakukan kajian lebih lanjut terkait bilangan kromatik lokasi graf-graf tersebut dan relasinya terhadap bilangan kromatik lokasi graf dasar yang digunakan.

\section{UCAPAN TERIMAKASIH}

Penulis mengucapkan terima kasih kepada Universitas Tanjungpura dan kepada penelitipeneliti yang karya-karyanya dijadikan rujukan dalam artikel ini.

\section{DAFTAR PUSTAKA}

Asmiati, A. (2016). The locating-chromatic number for certain of trees. Bulletin of Mathematics, 8(2), 125-131.

Asmiati., Yana, I. K. S.G., \& Yulianti, L. (2018). On the locating chromatic number of certain barbell graphs. International Journal of Mathematics and Mathematical Sciences, 2018. https://doi.org/10.1155/2018/5327504

Behtoei, A., \& Omoomi, B. (2016). On the locating chromatic number of the cartesian product of graphs. Ars Combinatoria, 126, 221-235.

Chartrand, G., Salehi, E., \& Zhang, P. (2000). The partition dimension of a graph. Aequationes Mathematicae, 59(1), 45-54.

Chartrand, G., Erwin, D., Henning, M. A., Slater, P. J., \& Zhang, P. (2002). The locating-chromatic number of a graph. Bull. Inst. Combin. Appl, 36(89), 101.

Ghosh, P., Mishra, S. N., \& Pal, A. (2015). Various labeling on bull graph and some related graphs. International Journal of Applications of Fuzzy Sets and Artificial Intelligence, 5, 23-35.

Irawati, \& Dina. (2013). Pelabelan total sisi ajaib pada graf bintang. Jurnal Matematika UNAND, 2(1), 85. https://doi.org/10.25077/jmu.2.1.85-89.2013

Kabang, N. K., Yundari, \& Fran, F. (2020). Bilangan kromatik lokasi pada graf bayangan dan graf middle dari graf bintang. BIMASTER, 9(2), 329-336. https://doi.org/http://dx.doi.org/10.26418/bbimst.v9i2.39977

Munir, R. (2010). Matematika Diskrit Ed ke-3. Bandung: Informatika.

Thenmozhi, B., \& Prabha, R. (2017). Power domination of middle graph of path, cycle and star. International Journal of Pure and Applied Mathematics, 114(5), 13-19.

Xu, B., Li, C., \& Fan, Z. (2018). On locating numbers of graphs. Journal of Harbin Institute of Technology (New Series), 25(1), 93-96. https://doi.org/10.11916/j.issn.1005-9113.16198

Yuliantina, S., \& Budayasa, I. K. (2018). Beberapa syarat graf tidak bersahabat. Mathunesa: Jurnal IImiah Matematika, 6(2). 